Dhaka Univ. J. Biol. Sci. 24(1): 83-90, 2015 (January)

\title{
OPTIMIZATION OF FEEDING FREQUENCY ON THE GROWTH PERFORMANCE OF THAI PANGAS, PANGASIUS HYPOPHTHALMUS (SAUVAGE, 1878)
}

\author{
Md. Ali Husain, Anwar Hossain, Shankar Chandra Mandal, Md. Alamgir \\ KABIR AND MOHAMMAD SHAMSUR RAHMAN* \\ Department of Fisheries, Faculty of Biological Sciences, University of Dhaka, \\ Dhaka-1000, Bangladesh
}

Key words: Pangasius hypophthalmus, Feeding frequency, Growth performance

\begin{abstract}
Thai pangas, Pangasius hypophthalmus fingerlings were reared for 60 days in laboratory condition to investigate the effects of feeding frequency on the growth performance. The fish fingerlings in three treatments were fed with two, three and four times a day, respectively. During the feeding trial, growth and feed utilization were assessed by condition factor (K), average daily gain (ADG), specific growth rate (SGR) and feed conversion ratio (FCR). Significantly lower FCR $1.81 \pm 0.02$ and higher ADG $0.38 \pm 0.02$ and SGR $2.20 \pm$ $0.02 \%$ were found in fish fed thrice a day than that of other treatments $(p<0.05)$. Highest condition factor $1.69 \pm 0.13$ was found in fish fed four times a day while the lowest condition factor $0.77 \pm 0.03$ was detected in fish fed twice a day. Moisture content of Thai pangas in treatment $\mathrm{T}_{1}, \mathrm{~T}_{2}$ and $\mathrm{T}_{3}$ were $79.23 \pm$ $0.77,78.08 \pm 0.85$ and $77.84 \pm 0.17 \%$, respectively. The crude protein, crude lipid and ash contents were $16.11 \pm 0.00$ to $16.38 \pm 0.08 \%, 3.22 \pm 0.27$ to $3.41 \pm 0.06 \%$ and $1.47 \pm 0.02$ to $1.82 \pm 0.04 \%$, respectively. The findings of the present study demonstrated that three times feeding frequency showed better growth performance and nutritional composition of Thai pangas fingerlings.
\end{abstract}

\section{Introduction}

Thai pangas, Pangasius hypophthalmus is a fast-growing catfish which has recently become a very popular food fish and valuable aquaculture species in South-East Asia. The fish is extensively cultured by commercial fish farms in Thailand, India and Myanmar. It has been introduced to Bangladesh in 1990s and has since developed into a very popular species amongst fish farmers and consumers. The fish proved to be a great success in Bangladesh aquaculture and is the only catfish species used for commercial aquaculture in the country ${ }^{(1)}$.

Feed is the most important item for the viability and success of aquaculture particularly in terms of feed cost. Feed should be used optimally to prevent the input of

*Author for correspondence: <shamsur@du.ac.bd>. 
more nutrients than necessary. To avoid the waste of feed ingredients should increase the efficiency of food use and to reduce production costs. Feed cost is one of the largest operational costs in aquaculture (2). Therefore, the effort of feeding may be pointed as one of the most important element in the culture practice. The practice of feeding in an aquaculture system involves selection of appropriate ration sizes, feeding frequency and time of meal supply to the culture system. The growth of fish depends on the types of feed, feeding frequency, feed intake and its ability to absorb the nutrients. Feeding frequency is an important factor for the survival and growth of fish at the early stage ${ }^{(3,4)}$. Therefore, the present study was designed to investigate the feeding frequency by determining the growth performances for optimum aquaculture production of Pangasius hypophthalmus.

\section{Materials and Methods}

Thai pangas (Pangasius hypophthalmus) $(7.0 \pm 0.15 \mathrm{~cm}$ and $3.1 \pm 0.25 \mathrm{~g})$ fingerlings were obtained from the Brahmaputra fish hatchery at Mymensingh and transported to the rearing laboratory of the Department of Fisheries, University of Dhaka. The fingerlings were acclimated for two weeks prior to experiment. Nine circular tanks (each with 5001 pond water) were used in the present study in three treatments with three replicates each with ten fingerlings with continuous aeration. Fifty per cent water was exchanged every week with pond water. The fish fingerlings in three treatments were fed with 2, 3 and 4 times a day, respectively. The fingerlings were fed at the rate of $5 \%$ of their body weight. The sampling was done all the fishes in each tank at every 20 days interval and water quality parameters were observed weekly. During the feeding trial, the change in growth and feed utilization have been assessed by determining the condition factor $(\mathrm{K})$, average daily gain (ADG), specific growth rate (SGR) and feed conversion ratio (FCR). MEGA feed, Bangladesh, was used as experimental feed with 12\% (maxi.) moisture, 32\% (mini.) protein, $7 \%$ (mini.) lipid, 17\% (maxi.) ash, 6\% (maxi.) crude fiber, $2.1 \%$ (maxi.) calcium and $0.8 \%$ (mini.) phosphorus on the basis of per cent dry matter.

Sampling was accomplished at an interval of 20, 40 and 60th days of the experimental period. Prior to weighing fish were caught with a fine mesh scoop net and individual length and weight were recorded to the nearest centimeter and gram, respectively. After 60 days of rearing, the final length $(\mathrm{cm})$ and weight $(\mathrm{g})$ of the individual fishes were recorded by using measuring tap and electronic balance.

Specific growth rate $(\mathrm{SGR})(\% /$ day $)=[($ final weight $) \div($ initial weight $) /$ rearing period in days $\times 100$; Average daily gain $(\mathrm{ADG})=($ mean final fish weight $\div$ mean initial fish weight)/time $\left(\mathrm{T}_{2}-\mathrm{T}_{1}\right)$ and feed conversion ratio $(\mathrm{FCR})=[$ dry feed fed $(\mathrm{g}) /$ wet weight gain (g)] were estimated by Marimuthu et al.(5). The condition factor $(\mathrm{K})$ was determined by $\mathrm{K}$ $=\left\{\left(\mathrm{W} / \mathrm{L}^{3}\right) \times 100\right\}^{(6)}$, where, $\mathrm{W}=$ body weight $(\mathrm{g})$ and $\mathrm{L}=$ body length $(\mathrm{cm})$. 
The biochemical analysis was performed in the laboratory of Department of Fisheries, University of Dhaka. The moisture, crude protein, lipid, and ash contents of experimental fishes were determined by the standard methods (7).

Water temperature $\left({ }^{\circ} \mathrm{C}\right)$ and dissolve oxygen $(\mathrm{DO}, \mathrm{mg} / \mathrm{l})$ were measured by $\mathrm{HACH}$ DO meter (Model: HACH sension6, USA) and $\mathrm{pH}$ was measured by HANNA $\mathrm{pH}$ meter (HI 991001, USA) once in every week at 10 a.m. Data were analyzed by ANOVA followed by Tukey's HSD post hoc for multiple comparisons with the level of significance at $\mathrm{p}<0.05$ (using SPSS version 20).

\section{Results and Discussion}

Different growth performance parameters, namely condition factor $(K)$, average daily gain (ADG), specific growth rate (SGR) and food conversion ratio (FCR) were observed in Thai pangas at different feeding frequencies. The observed condition factor showed significant difference within the treatments (Table 1). At 60th day sampling, the highest value of condition factor was observed in treatment $T_{3}$ and the lowest value was found in treatment $\mathrm{T}_{1}\left(\mathrm{~F}=32.427, \mathrm{p}=0.001\right.$, Table 2). Condition factor found in treatment $\mathrm{T}_{3}$ was significantly higher than that of $\mathrm{T}_{1}$ and $\mathrm{T}_{2}$ at 40th day sampling. Condition factor was increasing with increasing feeding frequency as a result maximum $\mathrm{K}$ value was found at treatment $T_{3}$ as $1.71 \pm 0.16$ and lowest value was observed at treatment $T_{1}$ as $0.77 \pm 0.03$. As condition factor depends on the weight and length, so it may be due to higher feeding frequency the condition factor was increased. Rahman et al. showed the survival and growth of cat fish after giving selected supplemental feeds got the values of condition factor between $0.81-0.87$ percent $^{(8)}$.

Table 1. Condition factor $(\mathrm{K})$ during rearing period (Mean $\pm \mathrm{SEM}){ }^{1}$

\begin{tabular}{llll}
\hline \multirow{2}{*}{$\begin{array}{l}\text { Treatment (feeding } \\
\text { frequency a day) }\end{array}$} & \multicolumn{3}{c}{ Condition factor $(\mathrm{K})$} \\
\cline { 2 - 4 } & 20th day & 40thday & 60th day \\
\hline $\mathrm{T}_{1}(2$ times) & $0.78 \pm 0.06^{\mathrm{b}}$ & $0.77 \pm 0.04^{\mathrm{b}}$ & $0.77 \pm 0.03^{\mathrm{c}}$ \\
$\mathrm{T}_{2}$ (3 times) & $1.06 \pm 0.04^{\mathrm{ab}}$ & $1.17 \pm 0.01^{\mathrm{b}}$ & $1.14 \pm 0.04^{\mathrm{b}}$ \\
$\mathrm{T}_{3}$ (4 times) & $1.28 \pm 0.15^{\mathrm{a}}$ & $1.71 \pm 0.16^{\mathrm{a}}$ & $1.69 \pm 0.13^{\mathrm{a}}$ \\
\hline
\end{tabular}

${ }^{1}$ Values are mean \pm SEM of triplicate groups of 10 fish. Means in the same column with different superscripts are significantly different at $\mathrm{p}<0.05$.

Significant difference was found in average daily gain for pangas fingerlings while 3 times feed was used in a day during the rearing period ( $p<0.05$, Table 3$)$. At the end of 60 days rearing, the highest ADG value $(0.38 \pm 0.02 \mathrm{~g})$ was achieved by fish at treatment $\mathrm{T}_{2}$ (Table 4). On the other hand, the lowest ADG $0.12 \pm 0.01 \mathrm{~g}$ was found in $\mathrm{T}_{1}$ at 20th day. The result indicated feed affect on the average daily gain. Similar result was noticed in African catfish (Clarias gariepinus)(9). 
Table 2. ANOVA table for condition factor $(\mathrm{K})$ during rearing period.

\begin{tabular}{llcccc}
\hline $\begin{array}{l}\text { Date of } \\
\text { sampling (day) }\end{array}$ & Sources of variations & $\begin{array}{c}\text { Sum of } \\
\text { squares }\end{array}$ & $\begin{array}{c}\text { Degrees of } \\
\text { freedom }\end{array}$ & Mean square & F \\
\hline \multirow{3}{*}{ 20th } & Between treatments & 0.378 & 2 & 0.189 & 6.951 \\
& Within treatments & 0.163 & 6 & 0.027 & \\
& Total & 0.541 & 8 & & 23.193 \\
\multirow{3}{*}{40 th } & Between treatments & 1.326 & 2 & 0.663 & \\
& Within treatments & 0.171 & 6 & 0.029 & 32.427 \\
& Total & 1.497 & 8 & & \\
& Between treatments & 1.285 & 2 & 0.643 & \\
& Within treatments & 0.119 & 6 & 0.020 & \\
\hline
\end{tabular}

Table 3. Average daily gain (ADG) during rearing period (Mean $\pm S E M)$.

\begin{tabular}{lccc}
\hline Treatment & \multicolumn{3}{c}{ ADG $(\mathrm{g})$} \\
\cline { 2 - 4 } & $20^{\text {th }}$ day & $40^{\text {th }}$ day & $60^{\text {th }}$ day \\
\hline $\mathrm{T}_{1}$ & $0.12 \pm 0.01^{\mathrm{b}}$ & $0.13 \pm 0.02^{\mathrm{c}}$ & $0.14 \pm 0.00^{\mathrm{b}}$ \\
$\mathrm{T}_{2}$ & $0.17 \pm 0.01^{\mathrm{a}}$ & $0.35 \pm 0.03^{\mathrm{a}}$ & $0.38 \pm 0.02^{\mathrm{a}}$ \\
$\mathrm{T}_{3}$ & $0.12 \pm 0.01^{\mathrm{b}}$ & $0.22 \pm 0.01^{\mathrm{b}}$ & $0.21 \pm 0.02^{\mathrm{b}}$ \\
\hline
\end{tabular}

Table 4. ANOVA table for average daily gain (ADG) during rearing period.

\begin{tabular}{llcccc}
\hline $\begin{array}{l}\text { Date of } \\
\text { sampling (day) }\end{array}$ & Sources of variations & $\begin{array}{c}\text { Sum of } \\
\text { squares }\end{array}$ & $\begin{array}{c}\text { Degrees of } \\
\text { freedom }\end{array}$ & $\begin{array}{c}\text { Mean } \\
\text { square }\end{array}$ & F \\
\hline \multirow{3}{*}{20 th } & Between treatments & 0.005 & 2 & 0.003 & 9.966 \\
& Within treatments & 0.002 & 6 & 0.000 & \\
& Total & 0.007 & 8 & & \\
\multirow{3}{*}{40 th } & Between treatments & 0.075 & 2 & 0.038 & 28.670 \\
& Within treatments & 0.008 & 6 & 0.001 & \\
& Total & 0.083 & 8 & & \\
\multirow{2}{*}{60 th } & Between treatments & 0.086 & 2 & 0.043 & 53.316 \\
& Within treatments & 0.005 & 6 & 0.001 & \\
\hline
\end{tabular}

The highest specific growth rate $(3.66 \pm 0.01 \%)$ was detected in treatment $\mathrm{T}_{2}$ and the lowest value $(1.50 \pm 0.01 \%)$ was obtained in $\mathrm{T}_{1}$ (Table 5 ). All the treatments were significantly different among themselves at 60th day of sampling $(\mathrm{F}=99.686, \mathrm{p}=0.00)$ (Table 6). 
SGR progressively increased with the increase in feeding frequency and decreased with feed wastage. The significantly highest SGR in treatment $T_{2}$ might be due to the fact that the fish have utilized effectively the supplied feed taking small amount at a rate of three times a day. Hossain and Parween have recorded the highest SGR $(1.80 \%)$ in $H$. fossilis by supplemental diet which is similar to the present findings ${ }^{(10)}$. Wing-Keong et al. reported SGR as $1.27 \%$ /day fed with $5 \%$ of BW/day in bagrid catfish (Mystus nemurus) ${ }^{(11)}$.

Table 5. Specific growth rate (SGR) during rearing period (Mean \pm SEM).

\begin{tabular}{llcl}
\hline \multirow{2}{*}{ Treatment } & \multicolumn{3}{c}{ SGR $(\%)$} \\
\cline { 2 - 4 } & 20th day & 40 th day & 60 th day \\
\hline $\mathrm{T}_{1}$ & $2.74 \pm 0.05^{\mathrm{c}}$ & $1.83 \pm 0.35^{\mathrm{b}}$ & $1.50 \pm 0.01^{\mathrm{c}}$ \\
$\mathrm{T}_{2}$ & $3.66 \pm 0.02^{\mathrm{a}}$ & $3.58 \pm 0.01^{\mathrm{a}}$ & $2.20 \pm 0.02^{\mathrm{a}}$ \\
$\mathrm{T}_{3}$ & $2.98 \pm 0.02^{\mathrm{b}}$ & $2.96 \pm 0.06^{\mathrm{a}}$ & $1.73 \pm 0.05^{\mathrm{b}}$ \\
\hline
\end{tabular}

Table 6. ANOVA table for Specific growth rate (SGR) during rearing period.

\begin{tabular}{llcccc}
\hline $\begin{array}{l}\text { Date of } \\
\text { sampling (day) }\end{array}$ & $\begin{array}{l}\text { Sources of } \\
\text { variations }\end{array}$ & $\begin{array}{c}\text { Sum of } \\
\text { squares }\end{array}$ & $\begin{array}{c}\text { Degrees of } \\
\text { freedom }\end{array}$ & $\begin{array}{c}\text { Mean } \\
\text { square }\end{array}$ & F \\
\hline \multirow{3}{*}{20 th } & Between treatments & 1.388 & 2 & 0.694 & 219.710 \\
& Within treatments & 0.019 & 6 & 0.003 & \\
& Total & 1.407 & 8 & & \\
& Between treatments & 4.716 & 2 & 2.358 & 19.086 \\
40 th & Within treatments & 0.741 & 6 & 0.124 & \\
& Total & 5.457 & 8 & & \\
& Between treatments & 0.756 & 2 & 0.378 & 99.686 \\
& Within treatments & 0.023 & 6 & 0.004 & \\
& Total & 0.778 & 8 & & \\
\hline
\end{tabular}

Table 7. Feed conversion ratio (FCR) during rearing period (Mean \pm SEM).

\begin{tabular}{llll}
\hline Treatment & \multicolumn{3}{c}{ FCR } \\
\cline { 2 - 4 } & 20 th day & 40 th day & 60th day \\
\hline $\mathrm{T}_{1}$ & $2.75 \pm 0.07^{\mathrm{a}}$ & $2.78 \pm 0.08^{\mathrm{a}}$ & $2.83 \pm 0.05^{\mathrm{a}}$ \\
$\mathrm{T}_{2}$ & $1.85 \pm 0.01^{\mathrm{c}}$ & $1.91 \pm 0.01^{\mathrm{c}}$ & $1.81 \pm 0.02^{\mathrm{c}}$ \\
$\mathrm{T}_{3}$ & $2.46 \pm 0.02^{\mathrm{b}}$ & $2.49 \pm 0.06^{\mathrm{b}}$ & $2.43 \pm 0.09^{\mathrm{b}}$ \\
\hline
\end{tabular}

The lowest food conversion ratio $(\mathrm{FCR})(1.81 \pm 0.02)$ was observed in treatment $\mathrm{T}_{2}$ and the highest $(2.83 \pm 0.05)$ in treatment $\mathrm{T}_{1}$ (Table 7$)$. The lowest FCR value was an indication of better food utilization efficiency of supplemental feeds. All the treatments were 
significantly different among themselves $(\mathrm{F}=69.722, \mathrm{p}=0.00)$ (Table 8). The lower FCR value might be due to the feeding behavior of Thai pangas. The fish might be properly utilized most of the supplemental feed and the utilized feed helped in production of supplemental food by releasing nutrients through decomposition. Relatively better FCR value (1.624 \pm 0.083$)$ was detected by Marimuthu et al. in African Catfish (C. gariepinus) fingerlings by feeding twice a day ${ }^{(5)}$.

Table 8. ANOVA table for feed conversion ratio (FCR) during rearing period.

\begin{tabular}{|c|c|c|c|c|c|}
\hline $\begin{array}{l}\text { Date of } \\
\text { sampling (day) }\end{array}$ & Sources of variations & $\begin{array}{l}\text { Sum of } \\
\text { squares }\end{array}$ & $\begin{array}{c}\text { Degrees of } \\
\text { freedom }\end{array}$ & $\begin{array}{c}\text { Mean } \\
\text { square }\end{array}$ & $\mathrm{F}$ \\
\hline \multirow{3}{*}{ 20th } & Between treatments & 1.255 & 2 & 0.627 & 125.018 \\
\hline & Within treatments & 0.030 & 6 & 0.005 & \\
\hline & Total & 1.285 & 8 & & \\
\hline \multirow{3}{*}{ 40th } & Between treatments & 1.171 & 2 & 0.586 & 62.816 \\
\hline & Within treatments & 0.056 & 6 & 0.009 & \\
\hline & Total & 1.227 & 8 & & \\
\hline \multirow{3}{*}{60 th } & Between treatments & 1.572 & 2 & 0.786 & 69.722 \\
\hline & Within treatments & 0.068 & 6 & 0.011 & \\
\hline & Total & 1.639 & 8 & & \\
\hline
\end{tabular}

Table 9. Proximate composition of Thai pangas (Mean \pm SEM) at 60 days of rearing.

\begin{tabular}{cllll}
\hline Treatment & Moisture (\%) & Crude protein (\%) & Crude lipid (\%) & Ash (\%) \\
\hline $\mathrm{T}_{1}$ & $79.23 \pm 0.77$ & $16.11 \pm 0.00$ & $3.24 \pm 0.03$ & $1.47 \pm 0.02^{\mathrm{b}}$ \\
$\mathrm{T}_{2}$ & $78.08 \pm 0.85$ & $16.38 \pm 0.08$ & $3.22 \pm 0.27$ & $1.58 \pm 0.03^{\mathrm{b}}$ \\
$\mathrm{T}_{3}$ & $77.84 \pm 0.17$ & $16.34 \pm 0.12$ & $3.41 \pm 0.06$ & $1.82 \pm 0.04^{\mathrm{a}}$ \\
\hline
\end{tabular}

At the end of the rearing and feeding trial, investigations were carried out on the proximate composition of $P$. hypophthalmus for different feeding frequency. The biochemical composition of Thai pangas fish analyzed on dry weight basis. Average moisture content of Thai pangas in treatments $\mathrm{T}_{1}, \mathrm{~T}_{2}$ and $\mathrm{T}_{3}$ were $79.23 \pm 0.77,78.08 \pm 0.85$ and $77.84 \pm 0.17 \%$, respectively. Shaheen et al. observed that moisture content in catfish bacha and pabda were 72.2 and $73.7 \%$, respectively ${ }^{(12)}$. Average protein content of Thai pangas fish in treatments $T_{1}, T_{2}$ and $T_{3}$ were $16.11 \pm 0.00,16.38 \pm 0.08$ and $16.34 \pm 0.12 \%$, respectively. Shaheen et al. studied the protein content of the same species of catfishes in Bangladesh were in between 16.1 and $17.3 \%$, respectively ${ }^{(12)}$. Average fat/lipid content of Thai pangas fish in treatments $\mathrm{T}_{1}, \mathrm{~T}_{2}$ and $\mathrm{T}_{3}$ were $3.24 \pm 0.03,3.22 \pm 0.27$ and $3.41 \pm 0.06 \%$, respectively while Wimalasena et al. found 2.3\% lipid in stinging catfish (Heteropneustes fossilis)(13). In the present investigation, average ash content of Thai pangas fish in 
treatments $\mathrm{T}_{1}, \mathrm{~T}_{2}$ and $\mathrm{T}_{3}$ were $1.47 \pm 0.02,1.58 \pm 0.03$ and $1.82 \pm 0.04 \%$, respectively. WingKeong et al. investigated the ash content of bagrid catfish and recorded that mean ash content was $3.8 \%(\mathrm{w} / \mathrm{w})^{(11)}$. From the above discussion, it is clearly revealed that the protein content increased; moisture contents decreased and fat and ash contents fluctuated at the time of rearing and feeding trial.

During the study period water temperature was found in suitable range between $27.17 \pm 0.04$ and $27.20 \pm 0.04{ }^{\circ} \mathrm{C}$. The dissolved oxygen of the water was within the range of $5.50 \pm 0.17 \mathrm{mg} / \mathrm{l}$ to $5.97 \pm 0.03 \mathrm{mg} / \mathrm{l}$ and water $\mathrm{pH}$ was $7.10 \pm 0.06$ to $7.40 \pm 0.06$.

The results of the present study based on the growth parameters and proximate composition suggests that $P$. hypophthalmus fingerlings $(7.0 \pm 0.15 \mathrm{~cm}$ and $3.1 \pm 0.25 \mathrm{~g})$ should be fed at three times a day for maximum growth performances.

\section{Acknowledgement}

The research work was partially funded by Centre for Advanced Research in Biological Sciences, University of Dhaka, Bangladesh.

\section{References}

1. Rahman MM, MS Islam, GC Halder and M Tanaka 2006. Cage culture of sutchi catfish, Pangasius sutchi (Fowler 1937): Effects of stocking density on growth, survival, and yield and farm profitability. Aquacul. Res. 37: 33-39.

2. De Silva SS and FB Davy 1992. Fish nutrition research for semi-intensive culture system in Asia. Asian Fisheries Sci. 5: 129-144.

3. Dwyer KS, JA Brown, C Parrish and SP Lall 2002. Feeding frequency affects food consumption, feeding pattern and growth of juvenile yellow tail flounder (Limanda ferruginea). Aquacul. 213: $279-292$.

4. Hung LT, NA Tuan and J Lazard 2001. Effects of frequency and time of feeding on growth and feed utilization in two Asian catfishes, Pangasius bocourti (Sauvage, 1880) and $P$. hypophthalmus (Sauvage, 1878). J. Aquac. Trop. 16 (2):171-184.

5. Marimuthu K, AC Cheen, S Muralikrishnan and D Kumar 2010. Effect of different feeding frequency on the growth and survival of African catfish (Clarias gariepinus) fingerlings. Adv. Environ. Biol. 4: 187-193.

6. Hile R 1931. The rate of growth of fishes of Indiana. Investigations of Indiana Lakes, No. 2. Depart. Conser., Division of Fish and Game; Indiana, Publication No. 107, 1931, pp. 9-55. Indianapolis.

7. AOAC (Association of Official Analytical Chemists) 1995. Official Methods of Analysis of AOAC International. 16th ed. Association of Official Analytical Chemists, Washington DC.

8. Rahman MA, A Bhadra, N Begum and MG Hussain 1997. Effects of some selective supplemental feeds on the survival and growth of catfish (Clarias batrachus Lin.) fry. Bangladesh J. Fish. Res. 1 (2):55-58. 
9. Musiba MJ, GW Ngupula, BB Kashindye, M Elison, AP Shokol, J Ndikumana, EZ Ziwa and EFB Katunzi 2014. Performance of locally formulated feeds for rearing of African Catfish in Tanzania. African Cr. Sci. J. 22: 979-986.

10. Hossain MA and S Parween 1998. Effect of supplementary feed on the growth of shing fish (Heteropneustes fossilis Bloch). Bangladesh J. Fish. Res. 2(2): 205-207.

11. Wing-Keong NG, LU Kim-Sun, R Hashim and A Ali 2000. Effects of feeding rate on growth, feed utilization and body composition of a tropical bagrid catfish. Aquacult. Int. 8: 19-29.

12. Shaheen N, ATMA Rahim, M Mohiduzzaman, CP Banu, ML Bari, AB Tukun, MA Mannan, L Bhattacharjee and B Stadlmayr 2013. Food Composition Table for Bangladesh. INFS, CARS, University of Dhaka, Bangladesh. pp. 214.

13. Wimalasena S and MNS Jayasuriya 1996. Nutrient analysis of some fresh water fish. J. Natn. Sci. Coun. Sri Lanka 24(1):21-26.

(Manuscript received on 20 July, 2014; revised on 7 January, 2015) 